\title{
BAWEAN ISLAND COMMUNITY SURVIVAL STRATEGIES DURING THE COVID-19 PANDEMICS
}

\author{
Singgih Susilo ${ }^{\mathrm{I}}$, Novia Fitri Istiawati ${ }^{2}$, Ifan Deffinika ${ }^{3}$, Budijanto ${ }^{4}$ \\ ${ }^{1,3,4}$ Department of Geography, Universitas Negeri Malang, Malang, Indonesia \\ ${ }^{2}$ Department of Social Science Education, Universitas Lampung, Bandar Lampung, Indonesia \\ Corresponding Author Email: novia.istiawati@fkip.unila.ac.id
}

\begin{abstract}
This study aims to examine the strategies and actions of the people of Bawean Island in meeting food needs during the COVID-I9 pandemic by using Max Weber's theory of action. Extracting information was carried out using participatory observation techniques and in-depth interviews and was supported by documentation and analysis using inductive use. The results showed that there were two strategies and actions, namely: saving on food needs and limiting household expenses. Saving on food needs is done by changing the consumption pattern of side dishes. People are looking for replacement side dishes, for example; People who are accustomed to consuming fresh sea fish for a week in a row, have started to replace them with tofu, tempeh and rencek fish. The savings were made because during the pandemic, the traffic flow from Bawean Island to Java (Gresik) was not smooth, causing foodstuffs to increase in price and scarcity. Restrictions on household expenditure are carried out by reducing household spending and only focusing on spending on food, health, electricity and fuel oil needs. These two strategies can save household food and shopping needs, before the pandemic it was usually IDR I50,000 to IDR 70,000-80,000 per day. Furthermore, the actions taken by the people of Bawean Island, namely continuing to work at the main job and working side jobs to increase income. People who choose to keep working in the main job feel that they cannot do anything other than survive in this job, this is done by many furniture traders and entrepreneurs who in the end, because there are no customers, are forced to use their savings for their daily needs. People who choose to work sideby-side are more based because they do not have savings funds and have to increase their income, the people who work a lot on the side in this research are the fishermen.
\end{abstract}

Keywords: action; Bawean Island community; food needs; COVID-I9

\begin{abstract}
Abstrak
Penelitian ini bertujuan untuk mengkaji strategi dan tindakan masyarakat Pulau Bawean dalam memenuhi kebutuhan pangan selama pandemi COVID-Ig melalui menggunakan teori tindakan Max Weber. Penggalian informasi dilakukan dengan teknik observasi partisipasi dan wawancara mendalam serta didukung dengan dokumentasi dan analisis menggunakan induktif. Hasil penelitian menunjukkan bahwa terdapat dua strategi dan tindakan, yaitu: penghematan kebutuhan makan dan pembatasan pengeluaran rumah tangga. Penghematan kebutuhan makan dilakukan dengan merubah pola konsumsi lauk pauk. Masyarakat mencari lauk pauk pengganti, misalnya; masyarakat yang terbiasa mengonsumsi ikan laut segar selama seminggu berturut-turut, mulai menggantinya menjadi tahu, tempe dan ikan rencek. Penghematan tersebut dilakukan karena selama pandemi terjadi, arus lalu lintas Pulau Bawean ke Pulau Jawa (Gresik) tidak lancar, sehingga menyebabkan bahan makanan mengalami kenaikan
\end{abstract}


harga dan kelangkaan. Pembatasan pengeluaran rumah tangga dilakukan dengan menekan belanja rumah tangga dan hanya memfokuskan pada pengeluaran kebutuhan pangan, kesehatan, listrik dan bahan bakar minyak. Dua strategi tersebut dapat menghemat kebutuhan makan dan belanja rumah tangga, sebelum pandemi biasanya sebesar RpI50,000,- menjadi Rp70,000-80,000,- per hari. Selanjutnya, tindakan yang dilakukan oleh masyarakat Pulau Bawean, yaitu tetap bekerja pada pekerjaan utama dan bekerja sampingan untuk menambah pemasukan. Masyarakat yang memilih tetap bekerja pada perkerjaan utama merasa tidak dapat melakukan apapun selain bertahan pada perkerjaan tersebut, hal ini banyak dilakukan oleh pedagang dan pengusaha mebel yang pada akhirnya karena tidak ada pelanggan, terpaksa menggunakan uang tabungan untuk keperluan sehari-hari. Masyarakat yang memilih bekerja sampingan lebih didasarkan karena tidak memiliki dana tabungan dan harus menambah pemasukan, masyarakat yang banyak bekerja sampingan dalam penelitian ini adalah golongan nelayan.

Kata Kunci: tindakan; masyarakat Pulau Bawean; Kebutuhan Pangan; COVID-I9

\section{INTRODUCTION}

Food access refers to the affordability and allocation of food, as well as individual and household preferences. The UN Committee on economic, social and cultural rights notes that the cause of hunger and malnutrition is often not food scarcity but the inability to access available food, usually due to various factors, one of which is transportation (Bodrud-Doza, Shammi, Bahlman, Islam, \& Rahman, 2020; Dwivedi et al., 2020). Transportation is very important in terms of food distribution to various places to meet the basic needs of the community. Difficult access to transportation can lead to scarcity of basic necessities so that people will also find it difficult to meet their basic needs.

Basic needs are the main thing in human survival. This is no exception for the people of Bawean Island. The characteristics of the island's people are that most of them work as migrant workers (TKI) who every month of fasting and Eid-ul-Fitr holidays return to Bawean Island. His community background as a migrant worker also has serious consequences during the current COVID-I9 pandemic. TKI families who depend on their main income from family members who work as TKI currently do not get the monthly allowance sent by TKI. This is because migrant workers, mostly in Malaysia and Singapore, are facing temporary work stoppages due to the COVID-I9 pandemic which has reached an indefinite time limit. Most of the migrant workers are also unable to return to Bawean Island due to the implementation of lockdown (lockdown of large-scale areas) in the two countries and large-scale social restrictions (commonly known as Pembatasan Sosial Berskala Besar - PSBB) in Indonesia, as well as in East Java Province where Bawean Island is one of the sub-districts in Gresik Regency.

The conditions of full-time migrant workers and their families in Bawean Island face many problems related to the economic resilience of their families after they no longer work abroad, limited information, networks and technical matters that limit options for full-time migrant workers. This problem is currently exacerbated by the existence of a non-natural, non-social national disaster, namely the COVID-I9 pandemic. COVID-I9 (Corona Virus Disease 20I9) is a highly contagious disease with a long incubation period caused by Sars-Cov-2 (Severe Acute Respiratory Syndrome). Coronavirus 2) (Wyplosz, 2020). The number of COVID-I9 patients increased dramatically as hundreds of millions of people traveled during the initial period of the pandemic. The severity of COVID-I9 has been ruled out until the Ministry of Health of the Republic of Indonesia officially classified it as a type $\mathrm{B}$ infectious disease and took action to combat the disease on I2 March 2020. Since then, comprehensive epidemic prevention has been stepped up and marks the beginning of concern for the whole world as well as shows a wider impact, both from an economic, socio-cultural and environmental perspective (Baker et al., 2020).

The very serious impact felt by the community is the fulfillment of basic needs. This impact is very pronounced because Bawean 
Island is a remote and outermost island. The basic needs of the people in Bawean Island are very dependent on supplies from Java, especially Gresik and Surabaya. Goods that meet these basic needs will be carried using sea transportation from the Port of Gresik. During the COVID-I9 pandemic, the transportation of ships for passengers did not operate, in which case the passenger ship by the community also functioned as a means of transporting basic necessities. The pandemic period which is still ongoing and it is not known when it will end is a serious problem for the community because basic necessities will also be difficult to obtain. In connection with the COVID-I9 pandemic situation, the community must have a strategy (mitigation) to be able to maintain the fulfillment of basic needs.

The focus of the problem to be examined in this research is what actions or strategies and how the people of Bawean Island, especially the families of TKI, did in dealing with the scarcity of basic necessities during the COVID-I9 pandemic. The urgency of the research is also to find out how the people of Bawean Island survive with the consumption of basic necessities that can only be obtained from the remaining stocks before the COVID-I9 pandemic and what alternatives they use to survive.

In connection with the focus and objectives of the research mentioned above, to answer it requires an in-depth and comprehensive study of the people of Bawean Island. This study mainly emphasizes individual actions related to strategies implemented in meeting the basic needs of their families during the COVID-I9 pandemic. Individual actions will be seen naturally (reality) using the perspective guide of Max Weber's Rational Action theory. The theory states that a rational social action always leads to achieving goals (Ritzer and Goodman, 2012). Based on this perspective in this study, it is hoped that the findings will be obtained, namely; the social context of the community affected by the COVID-I9 pandemic, the rational action (strategy / mitigation) of individuals in society in obtaining and fulfilling basic needs during the COVID-I9 pandemic.
The basic idea of this study is that the community's strategic actions in obtaining basic needs due to the impact of COVID-I9 are a social reality. This research has a high originality value, because research into community strategic actions in obtaining basic needs due to the impact of COVID-I9 has never been conducted. Therefore, the long-term objective of the research is to find a community action strategy in an effort to survive (obtain and fulfill basic needs) during the COVID-I9 pandemic. The research objective will be achieved in several steps, namely; identification of community characteristics, problems that occur, and attitudes / actions chosen by the people of Bawean Island.

\section{RESEARCH METHOD}

This research belongs to the qualitative type with Weber's phenomenological approach. This is in line with Bandur's (20I7) opinion that qualitative research designs can include theoretical designs from that or grounded theory, ethnography, narrative, biography, and phenomenology. The designs are determined by the researcher based on the methodological view that the researcher believes in himself as well as the significance of the research problem being studied both for the development of science and for improving existing policies and practices. The characteristics that distinguish qualitative research from others are as follows. Qualitative research always has a natural background, the researcher's function is as an instrument, using participatory observation, in-depth interviews, literature study and documentation in data collection, data is analyzed inductively, grounded theory, processes are more important, research limitations are in the form of focus, research design is temporary and have specific criteria and data validity testing (Lincoln and Guba, 1985).

Qualitative research procedures need to be understood in order to be relevant and contextual. This is because since the early i980s, there has been a shift from quantitative to qualitative research. This shift is in the context of developing science, policy, practice in the fields of psychology, linguistics, public 
administration and others (Miles and Huberman, I994). The starting point of qualitative research in this research was social reality. This is based on the fact that human action has meaning for itself in a certain context. This action has aspects that will be understood through research, namely: humans act based on meaning, meaning is obtained from interaction relationships, and that meaning is always interpreted by Miles and Huberman (I995), Siahaan (1996), Zetline (1998) in Fatchan (Fatchan, 2013).

The theoretical foundation in qualitative research consists of several theories. The theory which is the basis of this research is; phenomenology (Moleong, 2009). This research will be conducted for 2 months on Bawean Island, Gresik Regency, East Java Province. The research conducted examines the strategic actions of the Bawean Island community in an effort to meet basic needs during the COVID-I9 pandemic. Data collection techniques were conducted by participatory observation, in-depth interviews, literature study, and documentation. The data verification strategy was implemented by using the Kappa Test using NVivo I2 Plus Software with three Data Coders.

The main source of data in this study were humans (informants) with all their phenomena, in this case the people of Bawean Island. Supporting data relates to data in the form of documents and pictures / photos related to the focus of the research. These documents can be in the form of books or literature related to strategies / actions in an effort to meet basic needs during the COVID-I9 pandemic.

Data analysis in this study employed NVivo I2 Plus software. The source of qualitative data in this study came from participatory observation, in-depth interviews, and documentation. The data verification strategy was carried out by using the Kappa Test using NVivo I2 Plus Software with three Data Coders.

\section{RESULT AND DISCUSSION}

Geographically, Bawean Island is located in the Java Sea, which is north of Surabaya-East Java. Astronomically, the island is located at
II $2^{\circ} 34^{\prime}$ - II2 ${ }^{\circ} 44$ East Longitude and $5{ }^{\circ} 43^{\prime}$ $5^{\circ} 52$ South Latitude. The area of this island reaches 80 miles or I20 kilometers which is not much different from the area of Surabaya which is 135.34 miles.

According to Hoogerwerf, Bawean Island was formed from the remains of an old volcano with a maximum height of 655 meters. Consists of alkaline rock containing silicon acid. The volcanic material consists mainly of leucite and nephelin rocks. The topography of Bawean Island is hilly. According to the oral story of the Bawean people, there are 99 hills on Bawean Island. This story has religious nuances. The number 99 is associated with the Asmaul Husna (the beautiful names of Allah). Bawean is known as an island that is rich in hills, when seen from a distance in the middle of the sea, it looks sharp hills. The hill is sandy soil with very fertile soil conditions. Soil conditions on Bawean Island are quite favorable for agricultural activities.

The air on Bawean Island is quite cool. The strong sea breeze causes the climate to be fresher than on the north coast of Java Island. The midday temperature is relatively moderate and most of the year there is relatively little difference in temperature. Rainfall is no different from that on the north coast of Java Island. Relatively high rainfall. All types of plants can grow well in Bawean. Such as rice, corn, sorghum, all types of vegetables, durian, longan, rambutan, red fruit, cloves, nutmeg, coffee and pepper.

The ring road of Bawean Island is $57 \mathrm{~km}$ long. Therefore, to get around on the island of Bawean, it only takes half a day by using a motorbike or car. The peak of this island is at an altitude of 656 meters in the middle of the island. The cliff wall faces the north side. Here there is a crater called Lake Kastoba, which is 24 hectares wide and has a depth of 139 meters. A deep ravine lies between the ridges of the mountains which are covered in protected forest. Protected forests are located on the peaks of the mountains, while other forests are production forests.

On the island of Bawean, there are a number of hot springs with a temperature of approximately 40 Celsius whose water contains 
sulfur. These hot springs are located in the villages of Sawahmulya, Gelam and Kepuhteluk. In Gunung Malang Hamlet, Patar Selamat Village, there are two caves in which ancient stone tools were found made of Chalcedon, along with sea corals that were said to have been brought by early humans to the cave. There are three waterfalls on Bawean Island, namely: Batu Lintang waterfall in Telukjati village, Kuduk-Kuduk waterfall in Patarselamat village and Laccar waterfall in Kebuntelukdalam village. This waterfall comes from small rivers in a protected forest that flow towards the sea. The rivers in Bawean are relatively small. The maximum width is 5 meters.

On this island, live a kind of endemic deer (Axis Hyelaphus Kuhlii) which is a rare species of deer in the world. Now the population of Bawean deer is approximately 320 individuals. 49 are in captivity and the rest are in protected forests. To preserve it, the Gresik Regency Government established a deer breeding ground in Tampoh Hamlet, Pudakit Barat Village. In this captivity, there are 42 female deer and 7 males.

Population dynamics on Bawean Island are very complex, namely in terms of population, population growth, early marriage, number of births, maternal mortality, and divorce. The total population of Bawean Island in 2018 reached 106,802 people, consisting of 53,869 men and 52,993 women. The number of young people, namely I5-16 years, reaches 9,I40 people. This number also consists of 4,510 men and 4,630 women (Statistics Indonesia, 2018). The majority of the population on Bawean Island work as farmers, working on rice fields and other food crops such as cassava and yams. Apart from being farmers, the people here also work as fishermen and migrant workers abroad, especially in Malaysia.

Strategy (mitigation) is needed by the people of Bawean Island. This community mitigation is expected to be able to overcome problems related to fulfilling basic household needs during the COVID-I9 pandemic. Actions to determine what strategy and how are needed, therefore the basic food needs of the Bawean Island people can be fulfilled. The actions of each household in society will certainly be dif- ferent, this is in line with Weber's opinion.

Max Weber, a sociologist with German nationality, is the originator of the theory of action, both social action and rational action. Weber introduced the concept that a human action is full of meaning. Rational action is an individual action whose ultimate goal is to achieve the goal.

According to Max Weber, social action is an individual action as long as the action has a meaning or subjective meaning for him and is directed to the actions of others. An individual action directed at an inanimate object does not fall into the category of social action, an action will be said to be a social action when the action is actually directed at another person (another individual).

Max Weber introduced the concept of a verstehen approach to understanding the meaning of one's actions, assuming that someone in acting does not only do it but also puts himself in the environment of thinking and behavior of others. The concept of this approach is more directed at a motive action on the goal to be achieved or to motive.

Weber specifically classifies social action which has subjective meaning into four types. On the basis of the rationality of social action, Weber distinguishes human social action into four types, the more rational social action is easier to understand:

I) Instrumental Rationality Action (Zwerk Rational) is a social action that is conducted by someone based on consideration and conscious choice related to the purpose of that action and the availability of the tools used to achieve it. This action has been carefully considered in order to achieve a certain goal. In other words, assessing and determining that goal and that action may be used as a way to achieve other goals.

2) Value Rational Action (Werk Rational), has the nature that the existing tools are only conscious consideration and calculation, while the goals are already in relation to absolute individual values. This social action has been considered beforehand because it prioritizes social values 
and religious values that it has.

3) Affective Action (Affectual Action), this social action is more dominated by feelings or emotions without intellectual reflection or conscious planning. Affective actions are spontaneous, irrational, and is an emotional expression of the individual. This act usually occurs on stimulation from outside that is automatic, hence it can be meaningful.

4) Traditional Action, in this type of action, a person displays certain behaviors due to habits acquired from the ancestors, without conscious reflection or planning. Weber's typology that is in line with the actions of the Bawean people in meeting basic needs during the COVID-I9 pandemic is a zweckrationalitat (rational) typology, which is an action taken by an individual or someone by considering goals as a tool used to achieve goals. The rational action of a household in the Bawean community, in selecting and determining strategies (mitigation) to fulfill basic needs as a result of the COVID-I9 pandemic, aims to achieve the goal, namely a strategic action in meeting the basic needs of its family efficiently and effectively. The rational action of a household in the Bawean community is expected to be able to anticipate the future as long as the COVID-I9 pandemic has not ended.

\section{Community Strategy in Defending Life during COVID-I9}

The inhabitants of Bawean Island were devastated during the COVID-I9 pandemic. This is related to the limited operating schedule for passenger and cargo ships from Java to Bawean and vice versa, which also limits the transportation of staple foodstuffs. On a normal day before the COVID-I9 pandemic, ships from Java to Bawean and vice versa sailed every day. There are two types of ocean liners in operation, fast boats and passenger and cargo ships. The fast boat sails three times a week from Gresik to Bawean with a scheduled departure at 09.0o WIB (western Indonesian time) and up to I3.0o WIB. This ship will sail back to Java
(Gresik) the next day with the same departure time. The number of passengers on this ship reaches 250 people and is not allowed to carry goods and vehicles. Passenger and cargo ships sail three times a week with a scheduled departure at 09.00 WIB and arrive at 08.00 WIB. This ship is allowed to carry a limited number of goods and vehicles, the number of passengers reaches 500 people. This ship will sail two days after docking at Bawean. There are several strategies adopted by the Bawean community, including: saving food needs and limiting household expenses.

\section{Eating Needs Savings}

The strategy of saving food needs, by some people of Bawean Island, is an option that must be done. This strategy is implemented in a way that usually consumes side dishes in the form of meat or fresh fish or chicken by a household before the COVID-I9 pandemic occurs. The rationality taken by the household resulted in a savings in spending on one day's needs for consumption of fresh fish, which could save money into 3 days for consuming side dishes of tofu and tempeh or small fish. Tempeh and tofu, which are a strategy for changing consumption patterns, are limited in number. This is because the soybean which is the main ingredient in making tofu and tempeh comes from Java. Thus, the community began to gradually make tempeh from peanuts which were widely grown by the Bawean people.

The Boro life model that has been undertaken by the community while working as a TKI, was re-practiced during the COVID-I9 pandemic that hit Bawean Island. Boro comes from the Javanese language, namely from the word "ngemboro" or "mboro" which can be interpreted to temporarily leave the village or place of residence to move to another village/ city/region/country with the aim of earning income, improving socio-economic status, at times Some people return to their village with money (remittances) and return to their destination. Boro is a person's effort to improve the socio-economic status in their village by leaving their temporary residence to work at their destination (Subadi, 20I4). The boro life phenomenon carried out by some residents of 
Bawean Island is not carried out by all family members. If the perpetrator is the husband, then his wife and children live at home or if the one who is boro is the wife, then the husband and children stay at home, as well as if it is their child, the parents stay at home. This boro phenomenon is evidence of the migration concept proposed by Todaro (1969) who is popular with the study of rural-urban mobility looking at the geographical distribution gap of the factors of production.

Several subjects such as Agus Marianto, Jumaidi, Ramadlan Fikri, Mohamad Nasir, Abdur Rasyid, adopted the strategy of saving lives during this pandemic. This is like narrative from Agus Marianto, namely:

“... In the current pandemic situation, my family and I must be able to survive until the situation returns to normal. My family chose a strategy to change their consumption pattern, which is usually a side dish of fresh chicken and fish, now to tofu, tempeh and small fish...".

Based on the subject's expression, it is crystal clear that the family of Mr. Agus Marianto made savings from consuming side dishes of chicken and fresh sea fish (before COVID-I9), currently only consuming these side dishes only once a week, the other day consuming side dishes to taste. Based on the narrative of the subject with the frugal model in fulfilling the side dishes of the household, it makes him more able to manage his household expenditure management. As long as his furniture business was affected by COVID-I9, in fact there was no income, therefore, in meeting household needs, he took the savings that the subject had. The subjects at the end of the interview hoped that the COVID-I9 pandemic could end soon so that their business could return to normal, return to normal income and no longer apply the saving model in meeting the side dishes of their families. This saving model was also carried out by the subject family named Jum'adi, as described below: ".. In very difficult financial times like to-
day because of the COVID-I9 pandemic,
in fulfilling my daily food needs, especial-
ly for daily side dishes, I make savings,
by consuming minimal side dishes but I
prioritize staying nutritious. Side dishes
of tofu or tempeh, and occasionally buy- ing fresh fish, if all the vegetables are left to pick, because all this time I have been working on vegetable farming ... "

From the subject's expression, it is clear that during the pandemic period, in fulfilling the needs of side dishes every day, they apply the eating needs saving model. The subject who worked as a Malaysian TKI, while returning to his hometown had no income at all, so the subject tried to farm vegetables, two months after the start of the pandemic, his vegetable farming business has paid off, in addition to meeting household needs, mainly the harvested vegetables are sold in the market. Another subject, Mohamad Nasir, who works as a food supply savings model, said that during COVID-I9, the purchasing power of the Bawean people was very low, therefore the shops or stalls that became customers complained, because their merchandise did not sell easily, as before COVID-I9. This condition has an impact on the subject's business, which usually runs out of basic food stocks twice a week, now in two weeks it doesn't necessarily run out, and this is exacerbated by customers paying when their merchandise is sold. The subject admitted that he had to be unemployed for a loan at Bank Jatim every month, for that in spending for food, the subject applied a saving model, as in the following narrative.

"... My business condition during the COVID-I9 pandemic has really worsened, I just want to be idle, just loan money every month, can't be sufficient, I have to sell one of the cars. This difficulty forces me to save on food needs, which I have never done so far. The need for side dishes, especially fresh fish, is only I to 2 times a week, the rest is tofu and tempeh ... “

From the subject's expression, it inspires that to save food needs, it is very, very forced, because the rational action of saving is only being done now. This saving had to be made because the income was very low, so that the subject was obliged to repay the Bank's loan every month which could not be fulfilled. The subject really hopes that the COVID-I9 pandemic will end soon so that conditions can recover as before and the business of the grocery's supplier can run smoothly again. This is 
in line with the results of research by Anggita, E., Karina, K., Suriyatni, N., \& Alfarizi, W. A. (2020) which stated that the distribution of basic food items experienced obstacles during the pandemic, especially to $3 \mathrm{~T}$ areas.

\section{Restrictions on Household Expenditures}

The limitation on household expenditure in question is a limitation imposed by one household to limit spending in one day. These restrictions include not buying unnecessary items, apart from the need for food, electricity, health and motor vehicle operations. This condition occurs in the field, such as a family head who before COVID-I9 gave his wife a daily allowance of IDR I25,000 in one day to IDR 60,000. This limitation model was carried out by one of the subjects due to the fact that during the COVID-I9 pandemic, his furniture business did not receive any orders at all or orders were not taken immediately because the person concerned also did not have the funds to make payments. In connection with these conditions, in the end the subject of the furniture business owner was forced to use his savings to meet the needs of his family and try to grow crops by planting vegetables.

"... one of the subjects named Mohamad Awi explained that before COVID-I9 gave his wife Rp. I50,000 for spending money, but during COVID-I9 and not working, he limited household expenses to $R p$. 75,00o in one day. He took the expenditure from a savings fund he $o b$ tained while working as a TKI in Malaysia. Mohamad Awi also said that the longer his savings were running low and he hoped that this pandemic would end soon so that he could return to work as a TKI in Malaysia...”.

Based on the narrative from Mohamad Awi, it can be understood that the subject limits household expenses more because he does not work or his business is very quiet from orders. if this condition continues, it is very possible for the people of Bawean Island to experience food insecurity and even hunger. Several subjects such as Mohamad Sahrul, Zaenal Arifin and Usman Faruk also faced problems related to limiting household expenditure. the subject, Zaenal Arifin, said the following.

\begin{abstract}
"... My strategy is to maintain life during COVID-I9, reduce my daily spending rations, I do this so that my savings while working as a guard for Indonesian migrant workers abroad do not run out quickly, because during the COVID-I9 pandemic, there is no there are people or prospective migrant workers who can go abroad. In this condition I really do not work or become unemployed, therefore for a strategy in order to survive I use a model of limiting household expenditure...”.
\end{abstract}

From the expression the subject can describe the subject who works as a guard for the departure of Indonesian migrant workers to Malaysia, it is very aware that during the COVID-I9 pandemic this is the most difficult period, because there is a prohibition for someone to travel abroad, more so the Malaysian state which until now is still running Lockdown for the arrival of foreigners, especially from Indonesia and other ASEAN countries. During this period, the subjects had the status of unemployed, thus it was a very rational choice if in this survival strategy there was a limitation on household expenditure. This expenditure limitation model action was also carried out by the subject Moh Syahrul, who owns the LPG and Gasoline business, as follows.

“... During this pandemic, the income from my business has decreased dramatically when compared to previous income. To deal with the lack of income while household expenses remain large, in a strategy to maintain household life, I did a model of limiting household expenses during the COVID-I9 pandemic, with the aim of balancing the decreasing income income...".

From this subject, Moh Syahrul explained that the strategy to maintain household food needs is by implementing a model of household expenditure restrictions. This was done because the subjects felt that during the COVID-I9 pandemic, the income from their business as LPG gas distribution had decreased drastically. The subject feels that this condition is only being felt now, as long as he has never been experienced as a distributor entrepreneur. The subject really hopes that the conditions for the COVID-I9 pandemic will return to normal soon. 
The strategy of survival and survival in a society is a conscious effort made by a person to meet the needs of life. Thus, it will be naturalized to survive in dynamic conditions from generation to generation. In this research study, the survival strategy in the midst of the COVID-I9 pandemic is an interesting thing to study, because striving to survive is a positive attitude and dynamic process for the progress of society itself which has limitations.

Based on the description above, the strategy carried out by the people of Bawean Island in surviving the pandemic is a passive strategy. This strategy is often carried out by keeping household expenses to a minimum. by making savings and limiting spending during difficult times, of course, will be very helpful in meeting needs.

\section{Community Rational Actions in Obtaining Food Needs}

The rational action of the community in obtaining food needs during the COVID-I9 pandemic is a strategy chosen by the community rationally with the aim that the community can obtain food needs. Some subjects chose to continue to pursue their main work, and there were some subjects who chose to work side-by-side, because of the income from their main job, while there was COVID-I9 it could not be a strategy in obtaining food needs.

\section{Keep working at the main job}

The main work is the work done by the subject before the COVID-I9 pandemic. This main job is done by the Bawean people who do not have the talent to find side jobs. This main work is carried out by the subject who opens a shop, a kiosk and the like. According to the subject's narrative, during the COVID-I9 pandemic, this business was very quiet without buyers, but this business has no other way to be maintained. The business that is most affected by the Covid regulation is the food stall business, with social restrictions, it was said the first week of the week, there were absolutely no buyers, customers or visitors to the shop, but when this interview was conducted the subject said that currently there are quite a lot of visitors, customers and buyers came to his shop, even though it was not as normal as before the COVID-I9 pandemic. Based on the strategy implemented by the people of Bawean Island in surviving, one of the rational actions taken is to continue working in the main job before the COVID-I9 pandemic, but by making savings and limiting household expenses.

Rational action in surviving during the COVID-I9 pandemic by continuing to work in the main job is the most effective way to deal with conditions that are happening in the Bawean community today. The rational action found in this study is instrumental rational action. This rational action can be seen in the savings strategy and the restrictions contained therein. This action aims at the effectiveness and efficiency that will be obtained by utilizing existing facilities. This instrumental rational action tendency is influenced by the characteristics of the Bawean Island community itself. This can be seen from the low quality of formal education and supported by the state of natural resources for the community to work to use it.

In this regard, the subject, Mohamad Sahrul, tells that the difficulty of fulfilling basic needs which is increasingly expensive is suspected due to the impact of the COVID-I9 pandemic which causes the distribution of staple foods from Java to Bawean Island not smoothly, ships that usually carry staple food only sail one times during the pandemic, he continued.

"... as a Gas Tube distributor business-
man, I really find it difficult to get stock,
which before the COVID-I9 pandem-
ic had never happened. The impact of
COVID-I9 has occurred that passenger
ships and goods from the Geresik port
did not sail, now the ship has sailed only
once, previously in one week there were 5
times sailing to Bawean. As a result, the
distribution of basic foodstuffs including
gas cylinders is not smooth, this condi-
tion triggers the difficulty of goods and
increases in prices...".

From the subject's expression, describing that during COVID-I9 it was difficult for him to distribute his subscribers, even the subject felt that he had received complaints from buyers and customers when he could 
not provide LPG gas. Besides that, the income also decreased because the merchandise was very reduced, but the subjects continued to pursue their main work, because the subjects believed that the COVID-I9 pandemic could end soon, and the business as a distributor of LPG gas could return to normal as before the COVID-I9 outbreak. Other subjects also do it by making and choosing to save money, very limiting expenses, but he still works as usual without looking for a side job or additional income, one of which is the subject Agus Marianto also continues to live his profession as a furniture entrepreneur even though orders are very few or not Yes, he only relies on savings to make ends meet and saves for household expenses, the subject continues to focus on making furniture, by designing and making furniture that sells quickly on the market, as in the following narrative.

\begin{abstract}
“...During COVID-I9, I continued to work on making furniture, this job is my only skill, so I don't try to work in other fields, even though there are very few buyers right now, it is even said that no one ordered my furniture. To meet the daily needs of my household, I use my savings, even though it is not large, but it can still be sufficient to meet the needs of the family for the next three months, especially for side dishes, while for rice needs, I do not buy from rice fields, only I have to live frugally in expenses for household needs...".
\end{abstract}

Based on the expression the subject has described in an effort to obtain staple foodstuffs, they still pursue their main job, even though the conditions are quiet, the subject is not interested in pursuing other jobs as a side job. The principle of continuing to pursue their main work even though the conditions were quiet was also carried out by the subjects Moh Nasir and Siti Ramlah. According to these two subjects, although their main business is not with buyers or customers, they are not interested in trying to work on other jobs as a side job. Both of them continue to open their main business, only they manage expenses for their household needs as economically as possible, because they are sure that the COVID-I9 pandemic will end soon, thus conditions will return to normal as before. This is reinforced by the narrative of the subject, Siti Ramlah, who worked to open a food stall.

"...My business conditions during COVID-I9 were very quiet, what's more there are social restrictions, many people eat at restaurants. My business is empty of visitors, but my shop is in the house and yard of Seniri, however I will continue to work at it anytime, I believe this condition will change to the way it was before, when the COVID-I9 pandemic returns to normal. I am not interested in trying anything else, especially I am a woman who is fifty years old...”.

Based on the expression of the subject Siti Ramlah, under whatever conditions the subject continues to pursue his main business, the reason is that the location of his business is in his own homestead, the subject does not have the slightest thought to open another business just because his main business is quiet with visitors.

\section{Side job}

One of the rational actions taken by the Bawean people in their efforts to obtain food needs during the I9 pandemic is by doing side jobs. This side job is recognized by the Bawean community as a rational action, which is an action that is more profitable than a loss. The side work done by the subject is more due to his temporary main job during COVID-I9, not being able to provide income. A side job is a job that a person has in addition to his main job. In fact, it is very possible that side income provides an income far greater than that of the main job. This fact is very different from the side job done by the subjects of the Bawean community, the results of the field research that the subject works side-by-side because it is not running the main job. This condition is due to the COVID-I9 pandemic that has hit the world, including the people of Bawean Island.

Some subjects, such as the subject of Mohammad Awi, Jum'Adi, Usman Farok, Kamsul Arifin, and Muhammad, chose to take rational actions to be able to obtain basic food needs, even then a side activity carried out was a type of work whose results were easily marketable, the results were primary needs. community, so that the results of side work are easy to earn 
money, as told by a subject named Jum'Adi who said as follows:

“... Due to the lonely condition for ordering furniture, I temporarily closed my business, and I am engaged in vegetable farming, very grateful to be able to pick vegetables every other day to sell at the market, the results are quite able to cover the needs and needs of my wife and children, and Farming vegetables, I.5 months after planting, I can enjoy the harvest...".

Based on the subject's expression, it is clear that he deliberately closed his main business for a while, in connection with the COVID-I9 pandemic, there were no orders for his furniture. The subject temporarily closed his business and switched to a side job as a vegetable farmer, whose business was behind his furniture workshop. According to the subject of vegetable farming, it is quite easy and does not take long for the bus to be tapped, maintenance only every morning and evening you have to do watering. This side business activity was also carried out by subjects Muhamad Awi, Kamsul Arifin, and Subject Muhammad who worked side-by-side as fishermen, this side job was never done before the COVID-I9 pandemic outbreak. These three subjects have almost the same goal that by working alongside fishermen for the catch is sold to the market, in addition to the household side dishes. The three subjects work side-by-side as fishermen is a rational action, by working as fishermen in addition to their catch can help as a side dish for their family's day, as well as a source of household income as long as their main job cannot be expected to earn during the COVID-I9 period, as stated. by the subject Kamsul Arifin who works primarily as a Port Porter in Bawean as follows.

"... During COVID-I9, there have been no ships docked for several weeks, because there are regulations from the local government, that passenger and cargo ships from Gresik Port to Bawean Port are temporarily suspended and may not sail. The absence of passenger and cargo ships leaning on Bawean makes my job unemployed, therefore I work side by side as a fisherman, and I am grateful that the results of working as a fisherman can help with my daily needs...".

Based on the expression, the subject pro- vides an explanation that the subject is greatly helped by his side job, which previously had COVID-I9, his income was smooth and can be ascertained, suddenly the ship was not allowed to dock, and was unemployed, in terms of having to meet the needs of 4 children and I wife. By working side by side as a fisherman, the subject is very grateful and feels helped by his income as a fisherman. A side job as the backbone of the family economy during the I9 pandemic was also experienced by the subject, Usman Faruk, aged 43 years. The subject is still young and handsome as a TKI Brunai Darussallam, the subject returns to Bawean, the goal is to return to the routine every six months, did not think that just a few weeks in Bawean the COVID-I9 outbreak came, so that until this field research was carried out, we did not know when to return to Bawean. Brunei country to work as TKI again. When the subject does not work as a TKI, automatically there is no income in the household. Working again as a TKI cannot be ascertained, the subject and his wife make fish crackers to sell by supplying them to kiosks, as the narrative follows:
"... I came back here for only one month, but only three weeks before one month there was an outbreak of the COVID-I9 pandemic, I have been at home for three months, and I don't want to be unem- ployed for a long time since these two months I invited my wife to open a fish cracker business for sale to stalls and in markets. His income is very helpful for his daily needs, so that the savings from working as a migrant worker have been intact since the cracker business was started. Before the business, he worked on the side to meet his daily needs using savings...".

Based on the results of the subject, his rational action is very precise and effective, because the side job as well as supporting the daily needs of his household, this side business will still be able to be continued by his wife, even though the subject has started working again as a TKI in Brunei Darussalam, of course after the pandemic outbreak. COVID-I9 is completely normal again. A side job is clearly a strategy to obtain basic household needs.

A very interesting research finding is that there are subjects who cannot do their main job, but on the other hand, they also don't have 
a side job. These subjects are some of the foreign workers, who during the COVID-I9 pandemic they returned home or were sent home to their home area of Bawean Island. Subjects during the COVID-I9 period in fulfilling the daily needs of their families using the savings they have, these savings are none other than the result of working while they are foreign workers, as stated by a subject named Akhmad Nari, a 53-year-old subject. He has been working abroad for a long time as a TKI. The subject who has been in Bawean really does not work, or is unemployed, in the event that his family members have three children and one wife. During COVID-I9, the subject in fulfilling the needs of his family took advantage of the savings from working as a TKI. The narrative of the subject, Akhmad Nari.

\section{"... As long as I returned home in Bawean, I did not have a job, to meet the needs of my family I relied on my savings, I did not know that until now it has been four months, I still have not had a job, in terms of expenses for necessities it re- mains, while income is not Yes, the sav- ings are running low because they con- tinue to be taken for daily needs, I hope that COVID-I9 will end soon and I can work abroad again as a TKI...".}

From the subject's expression, the subject actually wants to be able to work while at home so that he has an income to meet his household needs. So far, the subject who relies on savings money is also running low, the subject really hopes that the COVID-I9 pandemic will end soon so that the subject can work again abroad as a TKI.

\section{CONCLUSION}

The Bawean community during the COVID-I9 period was severely affected, especially in connection with the non-operation of passenger ships and cargo ships from Java Island. There are several strategies adopted by the Bawean community, including: saving on food needs and limiting household expenses.

The strategy of saving food needs, by some Bawean people, is an option that must be made. This strategy is carried out in a way that usually consumes side dishes in the form of meat or fresh fish or chicken by a household every day (before the COVID-I9 pandemic), switching to the household family saving model by consuming tofu, tempeh or crushed fish as side dishes. The rationality taken by the household resulted in a savings in spending on one day's needs for consumption of fresh fish, which could save money into an expense of 3 days for the consumption of side dishes of tofu and tempeh or rencek fish.

The limitation on household expenditure in question is a limitation imposed by one household to limit spending in one day. These restrictions include not buying unnecessary items, apart from the need for food, electricity, health and motor vehicle operations. This condition occurs in the field, such as one of the family heads who before COVID-I9 gave his wife a daily allowance of IDR 150,000 in one day to IDR 70,000-80,000.

The rational action of the community in obtaining food needs during the is pandemic is a strategy chosen by the community rationally with the aim that the community can obtain food needs. There are some subjects who choose to keep on doing their main job, and there are some subjects who choose to work on the side. The main work is work carried out by the subject before the pandemic period I9. This main work is still carried out by the Bawean people, because it is not possible to find other (side) jobs. This main work is carried out by the subject who opens a shop, a kiosk and the like. According to the narrative of the subject, during the COVID-I9 pandemic, it was very quiet without buyers, but this business will be able to recover to its original state when COVID-I9 returns to normal.

One of the rational actions taken by the Bawean people in their efforts to obtain food needs during the I9 pandemic is by doing side jobs. This side job is recognized by the Bawean community as a rational action, which is an action that is more profitable than loss. Side work done by the subject is more due to his temporary main job during COVID-I9, not being able to provide income. 


\section{REFERENCES}

Baker, S. R., Bloom, N., Davis Steven J., J., K. K., Sammon, M. C., \& Viratyosin, T. (2020). The Unprecendeted Stock Market Impact of COVID-I9. NBER Working Paper Series, (26945), I689-I699.

Bandur, A. (2017). Penelitian Kualitatif: Studi Multi-Disiplin Keilmuan Dengan Nvivo I2 Plus. Jakarta: Mitra Wacana Media.

Bodrud-Doza, M., Shammi, M., Bahlman, L., Islam, A. R. M. T., \& Rahman, M. M. (2020). Psychosocial and SocioEconomic Crisis in Bangladesh Due to COVID-I9 Pandemic: A PerceptionBased Assessment. Frontiers in Public Health, 8(June). https://doi.org/Io.3389/ fpubh.2020.0034I

Dwivedi, Y. K., Hughes, D. L., Coombs, C., Constantiou, I., Duan, Y., Edwards, J. S., ... Upadhyay, N. (2020). Impact of COVID-I9 pandemic on information management research and practice: Transforming education, work and life. International Journal of Information Management, 55(July), I022II. https://doi. org/IO.IOI6/j.ijinfomgt.2020.IO22II

Fatchan, A. (2013). Metode Penelitian Kualitatif, Pendekatan Etnografi dan Etnometodologi Untuk Penelitian-Penelitian Ilmu- Ilmu Sosial. Yogyakarta: Ombak.

Huang, C., Wang, Y., Li, X., Ren, L., Zhao, J., Hu, Y., ... Cao, B. (2020). Clinical features of patients infected with 2019 novel coronavirus in Wuhan, China. The Lancet, 395(I0223), 497-506. https://doi. org/Io.Ioi6/SoI40-6736(20)30183-5

Huynh, T. L. D. (2020). The COVID-I9 risk perception: A survey on socioeconomics and media attention. Economics Bulletin, 4O(I), I-8.

Li, S., Wang, Y., Xue, J., Zhao, N., \& Zhu, T. (2020). The impact of COVID-I9 epidemic declaration on psychological consequences: A study on active weibo users. International Journal of Environmental Research and Public Health, I7(6). https://doi.org/ı0.3390/ ijerphi7062032

Lincoln, Y.S \& Guba. (1985). Naturalistic Inquiry. Beverly Hill: CA-SAGE Publications.

Martin, A., Markhvida, M., Hallegatte, S., \& Walsh, B. (2020). Socio-economic impacts of COVID-I9 on household consumption and poverty. ArXiv. https:// doi.org/I0.1007/s4I885-020-00070-3

McKibbin, W., \& Fernando, R. (2020). The Global Macroeconomic Impacts of COVID-I9: Seven Scenarios. Asian Economic Papers, I-55. https://doi. org/Io.II62/asep_a_00796

Miles, M.B., \& Huberman, A.M. (1994). Analisa Data Kualitatif. Jakarta: UI Press.

Moleong, L.J. (2009). Metodologi Penelitian Kualitatif. Bandung: Rosda.

Nicola, M., Alsafi, Z., Sohrabi, C., Kerwan, A., Al-Jabir, A., losifidis, C., ... Agha, R. (2020). The socio-economic implications of the coronavirus pandemic (COVID-I9): A review. International Journal of Surgery, 78(April), I85-I93. https://doi. org/I0.IoI6/j.ijsu.2020.04.018

Poudel, K., \& Subedi, P. (2020). Impact of COVID-I9 pandemic on socioeconomic and mental health aspects in Nepal. International Journal of Social Psychiatry, 66(8), 748-755. https://doi. org/I0.II77/0020764020942247

Ritzer, G., \& Goodman, D.J. (2012). Teori Sosiologi Modern, Ed. Ke-6, (translation: Alimanda). Jakarta: Prenada Media Group

Subadi, T. (20I4). Boro: Mobilitas Penduduk Masyarakat Tegalombo Sragen (Doctoral dissertation, Universitas Airlangga).

Verma, A. K., \& Prakash, S. (2020). Impact of COVID-I9 on environment and society. Journal of Global Biosciences, 9(5), 73527363. Retrieved from https://www. mutagens.co.in/jgb/vol.09/05/090506. pdf

Wyplosz, C. (2020). I4 The good thing about coronavirus, In Economics in the Time of COVID-I9. Retrieved from www.cepr.org 


\section{AUTHOR BIOGRAPHIES}

Dr. Singgih Susilo is a lecturer at Geography Department, Faculty of Social Science, Universitas Negeri Malang. He can be contacted by email at singgih.susilo.fis@ um.ac.id

Novia Fitri Istiawati is a lecture at Geography Study Program, Social Science Education, Faculty of Teacher Training and Education, Universitas Lampung. Novia can be reached by email at novia.istiawati@fkip.unila.ac.id

Ifan Deffinika is a lecturer at Geography Department, Faculty of Social Science, Universitas Negeri Malang. He can be contacted at ifan.deffinika.fis@um.ac.id

Prof. Dr. Budijanto is a proffessor of population science at Geography Department, Faculty of Social Science, Universitas Negeri Malang. He can be contacted by email at budijanto.fis@ um.ac.id 